\section{Commitment to Work and its Relationship with Organizational Culture Mediated by Satisfaction}

\author{
Lindomar Pinto da Silva ${ }^{1}$ \\ Miguel Angel Rivera Castro' \\ ${ }^{1}$ Salvador University, Post-Graduate Program in Management, Salvador, Brazil

\begin{abstract}
Marcos Gilberto Dos-Santos ${ }^{2}$
${ }^{2}$ Federal University of Bahia, Post-Graduate

Program in Management, Salvador, Brazil
\end{abstract} \\ Pedro José de Lima Netor \\ ${ }^{1}$ Salvador University, Post-Graduate Program in \\ Management, Salvador, Brazil
}

Received on

06/23/2017

Approved on

$04 / 25 / 2018$

Responsible editor:

Profa. Dra ${ }^{a}$. Gina Gaio Santos

Evaluation process:

Double Blind Review

\begin{abstract}
Purpose - The objective of this study is to analyze the mediating effect of satisfaction on the relationship between organizational culture and commitment at work.
\end{abstract}

Design/methodology/approach - This paper adopts a quantitative and descriptive approach, applying an online questionnaire to employees of a public development bank operating in the Northeast of Brazil. The analysis method involved the use of structural equations modeling.

Findings - The main results indicate that job satisfaction plays an important role in employee commitment, mediating the positive influence of organizational culture on commitment to work in its affective, instrumental, and normative dimensions in adhocratic cultures, and on affective commitment in clan cultures. They also indicate that satisfaction is a direct predictor of organizational commitment in the same way it mediates the relationship between culture and commitment.

Originality/value - This paper contributes to increasing the theoretical knowledge about the relationships established between culture, satisfaction, and commitment. For the area of people management, this knowledge can favor organizational performance, allowing managers to act more accurately in each of these constructs.

Keywords - commitment, satisfaction, organizational culture, mediation

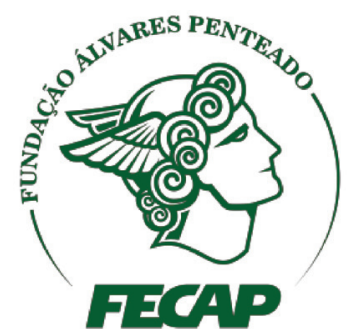

Review of Business Management

DOI: $10.7819 /$ rbgn.v20i3.3947 


\section{Introduction}

Research has sought to understand the effects of culture on satisfaction and commitment, albeit almost always separately. However, there are already some papers that seek, in the same study, to relate these concepts (Alvi et al., 2014; Bigliardi, Dormio, Galati, \& Schiuma, 2012; Habib et al., 2014; Medeiros \& Albuquerque, 2005; Santos \& Sustelo, 2009; Zhang \& Zheng, 2009). Organizational culture guides the behavior of the members of an organization. Therefore, it can play an important role in employee satisfaction and commitment. Taking the cultural model proposed by Quinn and Cameron (2006), some of its types, such as the clan culture and adhocratic culture, due to their characteristics of being aimed at the appreciation of personal relations and the autonomy of individuals, would enhance satisfaction and commitment, since these concepts are associated with the affective aspects of the individual in relation to the organization (Andrade et al., 2017; Bastos, 1993; Budihardjo, 2013; Locke, 1976; Monday et al., 1979; Siqueira, 2008).

Satisfaction can also provide significant increases in organizational commitment since both highlight the individual's affective ties with the organization. In this sense, it is expected that an organizational context in which levels of satisfaction are increased will result in an increase in the level of commitment of individuals (Leite, Rodrigues, \& Albuquerque, 2014; Maciel \& Camargo, 2011; Tett \& Meyer, 1993).

Despite these studies, it is still necessary to understand the broader relationships between these concepts, which is consistent with Leite et al. (2014), considering that there are gaps to be filled by the surveys to understand the relationship between commitment and satisfaction, especially taking into account other factors of the organizational context. It is in this space that this study is situated, using a contextual element, organizational culture, as a predictor of organizational commitment mediated by satisfaction.
Cultures that are more focused on the affective aspects and valuing the individual (Cameron \& Quinn, 2006) would tend to increase satisfaction and commitment. As satisfaction would also tend to increase commitment, it is expected that in the relationship between organizational culture and commitment, increases in satisfaction levels would also tend to increase the positive effect of the relationship between organizational culture and organizational commitment. Hence, the objective of this study is to analyze the mediating effect of satisfaction on the relationship between organizational culture and commitment at work.

The locus of this study is a public bank that operates in the Northeast region of Brazil. The banking segment has been seen as an environment that is conducive to problems such as moral harassment and illness due to management systems, work overload, pressures for results, and the constant technological advances that lead to increased unemployment in the segment. These phenomena can affect the levels of satisfaction and commitment of their workers (Andrade et al., 2013; Lima et al., 2014).

This paper contributes to increasing the theoretical knowledge about the relationships established between culture, satisfaction, and commitment. For the area of people management, this knowledge can favor organizational performance by allowing managers to act more precisely in each of these constructs. In order to achieve the objective of the study, this article is structured as follows. It begins with this introduction, followed by the theoretical reference, which discusses the concepts of culture, commitment, and satisfaction at work. Next, it presents the methodology of the research, followed by the analysis of the data and the results. Finally, the conclusions are presented.

\section{I Organizational culture}

Alvesson (2007, p. 5) views culture as "a more or less cohesive system of meanings and symbols in terms of which social interactions 
take place." This perception of culture as an element that shapes the relationships between the members of a community can be perceived in the definition given by Geertz (1989, p.4), which defines it as "a web of meanings woven by men." In this sense, culture is a set of normative social expectations that inform how the members of an organization should behave (Hartnell et al., 2011). This makes it an important element of the organizational context, since it guides the behavior appropriate to each context.

Although there is a significant amount of definitions of culture and approaches to it, this research used the approach of Cameron and Quinn (2006, p.17), for whom "the culture of an organization is reflected in the dominant leadership styles, in language and symbols, in procedures and routines, and in the definitions of success that make a single organization. "In order to measure the organizational culture of an organization, these authors use the Organizational Culture Assessment Tool (OCAI) derived from the Competing Values Framework (CVF) proposed by Quinn and Rohrbaugh (1983).

In the CVF, three dimensions are used as criteria for organizational effectiveness: the structure dimension, which represents the opposition between flexibility and stability; the focus dimension, which represents the internal or external orientation; and the values dimension, which is represented by the concern with the means or ends in the organization (Cameron $\&$ Quinn, 2006; Hartnell et al., 2011; Quinn \& Rohrbaugh, 1983). These three dimensions are arranged in four quadrants that form the cultural types Hierarchy, Market, Clan, and Adhocracy (Cameron \& Quinn, 2006).

The hierarchical culture has an internal orientation. It values stability, control, and integration. According to Quinn and Rohrbaugh (1983), the means used are mechanisms of information management and communication to achieve stability and control. For Hartnell et al. (2011), the underlying belief is that employees fulfill their expectations through the clear definition of their roles. Efficiency is achieved through predictability, guaranteed by clear and standardized rules (Cameron \& Quinn, 2006). Thus, efficient communication and standardization ensure organizational success (Denison \& Spreitzer, 1991; Strese et al., 2016).

The market culture can be considered a model of rational goals (Quinn \& Rohrbaugh, 1983). It focuses on the external environment and control. To achieve productivity and efficiency goals, it prioritizes goal planning. Competitiveness and the surpassing of goals are valued (Alvi et al., 2014; Braga et al., 2014; Cameron \& Quinn, 2006; Fernandes et al., 2015). The belief is that valuing organizational performance results in an increase in competitiveness, leading to greater productivity (Cameron \& Quinn, 2006; Hartnell et al., 2011). According to Hartnell et al. (2011), in this culture, well-defined goals and appropriate reward systems motivate employees.

The clan culture is associated with the human relations model (Quinn \& Rohrbaugh, 1983). This is because it values integration and team spirit as a means to achieve the development of human resources (Quinn \& Rohrbaugh, 1983). Hartnell et al (2011) add that communication, participation, and cohesion are also means to increase employee commitment. This involves shared values and goals, a sense of belonging, teamwork, and corporate commitment by the employees (Alvi et al., 2014; Braga et al., 2014; Cameron \& Quinn, 2006; Fernandes et al., 2015). For Hartnell et al (2011), the belief is that commitment from an employee results in the development of affection towards the company. Commitment and satisfaction shown by employees are criteria for the success of the organization (Hartnell et al., 2011; Strese et al., 2016).

In the adhocratic culture, according to Quinn and Rohrbaugh (1983), the model is one of open systems. It focuses on flexibility and adaptability to the external environment as a means to achieve growth and obtain resources from companies. Entrepreneurship, creativity, 
and an emphasis on individuality also stand out in this culture (Alvi et al., 2014; Braga et al., 2014; Cameron \& Quinn, 2006; Fernandes et al., 2015). For Hartnell et al. (2011), the belief in this culture is that resources and new businesses stem from processes of change. Since innovation is the criterion for success in this culture, creativity and risk taking are important means to achieve it (Hartnell et al., 2011; Strese et al., 2016).

\subsection{Satisfaction with Work}

Tamayo (2001) states that satisfaction includes a multi-factorial feature that is reflected in many elements of the organizational environment, such as compensation, organizational climate, relationships with colleagues and superiors, and career expectations, among other elements. This same perception can be seen in the paper by Spector (1985) when he describes the instrument for evaluating job satisfaction and divides its scale into nine facets (dimensions) that can influence this. In Warr's view (2007), there are at least 12 groups of characteristics that are positively associated with job satisfaction. This conclusion is reinforced by Hauff et al. (2015), quoting the work by Warr (2007), who reviewed the publications on the antecedents of satisfaction and concluded that, in fact, it is a construct that is influenced by diverse factors, which may hamper a full understanding of it.

Because of the diversity of the antecedents of satisfaction, its definition also involves difficulties of uniqueness. In Locke's view (1976), it can be considered as an individual evaluating their experiences at work as being pleasant or positive, where the elements of the organizational environment and the work itself are important conditioning factors. Similar to this perspective, Sánchez-Sellero et al. (2014) believe that the individual develops expectations about their work and, in doing so, compares the actual work with those expectations. The closer the work is to the expectation, the more the individual will feel satisfied.

In addition to the expectation of the individual, satisfaction also has an affective or emotional component (Andrade et al., 2017; Locke, 1976; Martins \& Santos, 2006; Siqueira, 2008). In this aspect, satisfaction would indicate the level of happiness that the individual feels in relation to their work. This emotional state would ensure work behaviors that are desired by the organization, since it leads the individual to have higher levels of performance than those who are not satisfied in their work. It is from this perspective that satisfaction is considered as a construct of an affective nature and that it is able to signal behaviors at work (Bigliardi et al., 2012; Hauff et al., 2015; Rodrigues, Barriquello, \& Morin, 2016; Sánchez-Sellero et al., 2014; Siqueira, 2008).

To capture the satisfaction of the individual in the workplace, Spector (1985, p. 695) defined it as the "representation of a grouping of evaluative feelings about work, an attitude variable that reflects how a person feels about work in general and in its various aspects". From this definition, he created the Job Satisfaction Survey (JSS), a 36item scale divided into nine dimensions with four items per dimension (Spector, 1985).

Using the Job Satisfaction Survey, one can assess the individual's overall satisfaction with the work or their satisfaction from the dimensions proposed by Spector (1985). Here, it would be possible to identify both general satisfaction and in which dimensions the individual is more satisfied with the work (Oliveira \& Costa, 2016; Tett \& Meyer, 1993), allowing the organization to act in order to provide higher levels of satisfaction in those dimensions where the individual showed less satisfaction with the job.

Based on the work by Spector (2006), Roman et al. (2012) divided the nine dimensions of satisfaction into three groups: a) Rewards: salary, promotion opportunities, and benefits; b) Relationship: supervision, co-workers, and working conditions; c) Nature of work: nature of work, communication, and safety. From this classification by Roman et al. (2012), one dimension of each group was chosen for this research. From the Rewards group, promotion 
opportunities was chosen, which means the individual's level of contentment with the possibilities offered by the company to progress in their career, involving both the position and the time that elapses between promotions and their criteria. From the Relationship group, the supervision dimension was chosen. It represents the degree of contentment of the individual with their superior both with regard to the treatment given and their ability to perform the work. Finally, from the Nature of work group, the nature of the work was selected, which refers to the interest of the individual in the task they perform in the organization (Spector, 2006).

These facets were chosen for the following reasons. Promotion opportunities involve other elements besides wages and benefits, as they include the employee's future expectations. The relationship with supervision is an important element in how day-to-day work is performed and it can directly interfere both in the relationship with colleagues as well as in the work conditions. Studies have shown high rates of moral harassment by managers in the banking sector (Lima et al., 2014). In turn, many of the activities in the banking sector tend to be standardized, which limits the worker's chances of autonomy. In this sense, the perception regarding this criterion of satisfaction is more relevant than the other items. The sector itself has presented high levels of illness due to the characteristics of the work (Lima et al., 2014).

\subsection{Organizational Commitment}

According to Mowday, Steers, and Porter (1979), the central interest of the research on commitment lies in the possibility of understanding which organizational outcomes result from the level of commitment that each individual has. There is a relationship between the level of commitment of an individual and their performance at work. This is because commitment is a link that binds the individual to the organization, leading them to make sacrifices on behalf of it. Committed individuals tend to want to stay in an organization longer than those who are not committed to it (Oliveira \& Costa, 2016; Rocha \& Honório, 2015).

It is in this sense that Becker (1960, p.33) considers that commitment causes the worker to follow "lines that are consistent with the organization." The conception of lines that are consistent with the organization is reinforced in what Bandeira, Marques, and Veiga (2000) affirm when they say that commitment makes the individual dedicate his/her loyalty and energy to the organization. Therefore, for Rodrigues, Barrichello, and Morin (2016), commitment portrays how strong the link between the individual and the company is. In addition, even though they recognize that other elements may affect an individual's behavior at work, Mowday et al. (1979, p.228) consider that the committed individual will present at least three attitudes: “(1) a strong belief in and acceptance of organizational goals and values; (2) the willingness to exert considerable effort on behalf of the organization; and (3) a strong desire to maintain participation in the organization."

The literature has presented three dimensions of commitment based on the threedimensional model developed by Meyer and Allen (1991). In this model, commitment is thought to be divided into affective, instrumental, and normative. The affective dimension highlights the identification of the individual with the values and objectives of the organization, as well as his/her loyalty and desire to remain in the organization, and for this reason he/she strives for the good of the organization (Bastos, 1993; Monday et al., 1979; Pires et al., 2015). For Siqueira and Junior (2004), this type of commitment stands out from the others in terms of the individual's desire to remain in the organization because he/she develops an affective connection with it. This understanding is shared by Budihardjo (2013), who considers affective commitment as the one most associated with satisfaction and performance, since the individual remains in the organization because he/she wants and not 
because he/she needs or is obliged to do so (Allen \& Meyer, 1990).

In the instrumental approach, the individual remains in the organization more because of the rewards received and he/she considers the costs or losses that would incur in a decision to leave the organization (Allen $\&$ Meyer, 1990; Bastos, 1993; Silva \& Bastos, 2010). Thus, there is a rational process of analysis in which the worker evaluates the benefits obtained in the organization and the costs associated with the loss, which would determine whether or not he/she remained in the organization. Thus, in this type of commitment, the individual remains in the organization because he/she needs to or because he/she would not obtain similar benefits in another one (Bastos, 1993).

The normative approach considers that committed individuals remain in an organization because they believe that it is morally correct (Medeiros et al., 2003; Weiner, 1982). According to Bastos (1993, p. 58), this commitment occurs due to the "set of normative pressures internalized by the individual so that he/she behaves according to the objectives of the organization". Hence, since the organizational culture reflects the set of values and patterns that determine what is right to do in the organization (Hartnell et al., 2011), this tends to influence the development of normative commitment (Medeiros et al., 2003; Rocha et al. Honório, 2015). Moreover, the individual considers him/herself to be a debtor of the organization and therefore accepts personal sacrifices in favor of it and must maintain an attitude of gratitude (Bastos, 1994; Siqueira \& Junior, 2004).

\subsection{Conceptual articulation}

Studies have shown that the organizational culture can influence organizational satisfaction and commitment. Cultures focused on aspects such as valuing the individual, including their well-being, autonomy, and flexibility, can favor increases in satisfaction and commitment. This would be due to the fact that satisfaction and commitment, especially the affective and normative types, have affective aspects that are similar to those that characterize, for example, clan and adhocratic cultures (Andrade et al., 2013; Bigliard et al., 2012; Cameron \& Quinn, 2006; Locke, 1976). However, due to their characteristics, market-type and hierarchical cultures favor instrumental commitment, since in these cultures the individual has no affective ties with the organization (Gull \& Azam, 2012; Hauff et al., 2015; Meyer \& Allen, 1991).

On the other hand, satisfaction and commitment would also be related as they have similar characteristics, especially satisfaction and affective and normative commitment since there are affective elements between the individual and the organization. Thus, satisfied individuals improve their level of commitment (Budihardjo, 2013; Falkenburg \& Schyns, 2007; Oliveira \& Costa, 2016; Tett \& Meyer, 1993). However, for the mediation by satisfaction between culture and commitment, given the exploratory nature of this study and the rarity of previous research about this relationship, the choice was made not to adopt hypotheses to be tested in this investigation. Thus, based on the objective of the research, the relationships between culture and commitment mediated by satisfaction will be identified using the empirical data.

\section{Methodology}

This study adopts a quantitative and descriptive approach, applying an online questionnaire to employees of a public development bank operating in the Northeast of Brazil. The questionnaire was emailed to all employees and was available on the Google Docs platform. The questionnaires were applied between August and December of 2016 and also contained questions aimed at characterizing the sample: age group, gender, marital status, schooling, undergraduate course, hierarchical level, and time in the company. The average time taken to answer the questionnaire was 15 minutes.

The sample is made up of 405 employees, $65 \%$ male and $43 \%$ aged between 31 and 40 . 
$76 \%$ of the respondents have a full degree and $52 \%$ have taken a specialization or post-graduate course. Among the graduates, the most common course is Business Administration (32\%), followed by Accounting and Engineering ( $9 \%$ each), and then Economics (7\%). Other courses accounted for $43 \%$ of the graduates. In relation to position held in the bank, 64\% work in management positions and $34 \%$ work in technical functions. Among the respondents, 35\% have worked in the bank for up to 5 years, followed by $26 \%$ who have been in the bank for between 5 and 10 years. $40 \%$ of the respondents have worked in the bank for more than 10 years.

The model that was adopted considers culture as an element of the environment that is capable of influencing satisfaction and organizational commitment, and in which satisfaction is also capable of influencing commitment. It will be tested whether the mediation by satisfaction influences the relationship between culture and commitment at work. The concepts presented here are measured based on three scales: Culture, developed by Cameron and Quinn (2006); Satisfaction at work, developed by Spector (1985), both translated and validated in the Brazilian context with a reduction in their dimensions by Silva, Castro, and Santos (2018); and Commitment, developed by Meyer and Allen (1991) and validated in the Brazilian context by Medeiros and Enders (1998) and Bandeira, Marques, and Veiga (2000).

Figure 1 represents the general model to be used in this research. Four models are generated from it to be analyzed together with the cultural types proposed by Cameron and Quinn (2006).

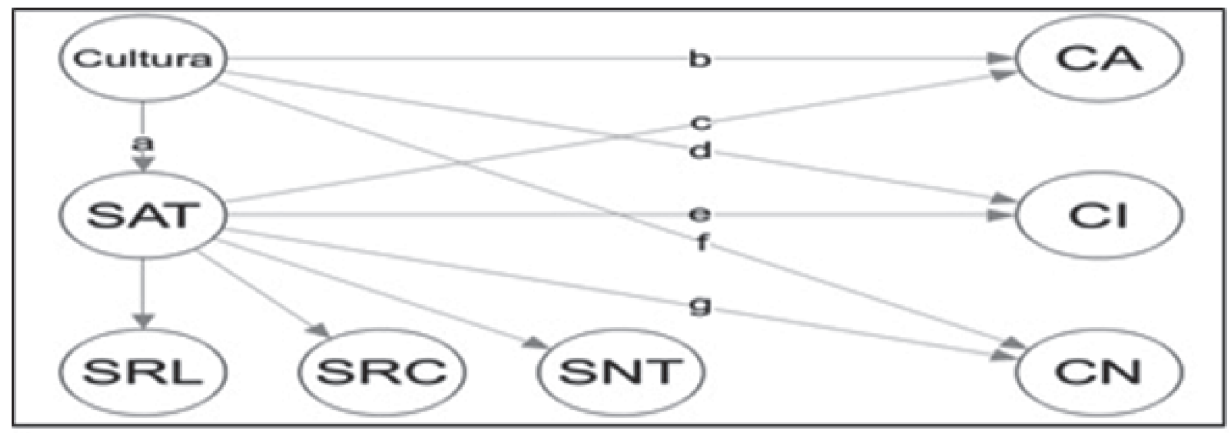

Figure 1. Analysis model

Note: The letters a, b, c, d, e, f, and g represent the estimates of the relations between the variables culture, satisfaction, and commitment.

Source: the authors.

For the analysis of the relationships that were presented, Structural Equation Modeling (SEM) was used, which is useful for studying latent variables in relationships involving more than one endogenous (or explained) variable. For the SEM, the first step uses Confirmatory Factor Analysis (CFA) of the constructs involved, followed by the specification of the relationships between the constructs - structural model- both evaluated by adjustment indexes that verify the quality of the modeling. The main indexes used are the $\chi^{2}$ statistics for the model adjustment, which have to present lower values for the best models, the parameter $\chi^{2} / \mathrm{GL}$, which preferably presents values $<5$, in addition to the values of CFI and TLI, which have to be greater than 0.9, and RMSEA and SRMR error rates, which should be less than 0.08 (Hair et al, 2009).

The SEM operates with a set of regressions with the estimators calculated simultaneously from the co-variance matrix of the variables involved. In this study, the estimators are presented in non-standardized form, since the three scales used present Likert responses from 
1 to 5 . In addition to the estimators, one can calculate the indirect effect of mediation from one variable to another. Mediation occurs when changing a mediating variable $\mathrm{X}_{2}$ changes the influence of the explanatory variable $\mathrm{X}_{1}$ on the explained variable $Y_{1}$ (Hair et al, 2009). In the model presented in Figure 1, the effect of the mediation by satisfaction in the relationship between culture and commitment will be verified by the indirect effect for affective commitment (CA), for instrumental commitment (CI), and for normative commitment $(\mathrm{CN})$. It is particularly interesting to verify the differences between the direct effect of the culture on commitment and the indirect effect of this relationship mediated by satisfaction (Vieira, 2009). In order to operationalize the research objective, four models were constructed based on the analysis model in Figure 1, considering each type of culture as an exogenous (explanatory) variable.

Thus, the models will be evaluated in terms of their indexes of adjustment to identify those that fulfill the parameters. Once the appropriate models have been identified, the relationships between the constructs studied are verified so as to identify the explanatory power of culture over satisfaction and culture and of satisfaction over the dimensions of commitment. In addition to these relationships, it will be verified whether the mediation by satisfaction has the power to modify the influence of culture on the dimensions of commitment at work. The data were analyzed using the statistical software $\mathrm{R}$ version 3.1.1 and the Lavaan package (latent variable analysis) version 0.5-20 (Rossel, 2012).

\section{Results}

In the preliminary analysis of the data, no multivariate normality of the data was verified. This problem was bypassed by the fact that the sample presented $n$ greater than 300 and with the adoption of the maximum likelihood estimator, capable of providing robust estimators for the violation of normality in large samples (Marôco, 2010; Olsson, Foss, Troye, \& Howell, 2000). The presence of outliers was verified by the function, in which is the Mahalanobis distance and g.l. is the degrees of freedom indicated by the number of variables involved (Hair et al, 2009), and no outliers were found in the sample used. Multicollinearity was assessed using the VIF (variance inflation factor), and all the values were within the acceptance parameters $(\mathrm{VIF}<5)$. As an initial stage of the structural equations modeling, confirmatory factor analysis (CFA) of the culture dimensions (Figure 2) was performed separately (clan, adhocracy, hierarchy, and market) in the first order; this was followed by satisfaction with its dimensions (relationship, reward, and the nature of the work) in the second order, and commitment at work with the dimensions of affective, instrumental, and normative commitment in the first order (Figure 3). The results are shown in Table 1.

Table 1

CFA results for the culture, satisfaction, and commitment constructs.

\begin{tabular}{|c|c|c|c|c|c|c|c|}
\hline Constructs & $\chi^{2}$ & GL & $\chi^{2} / \mathrm{GL}$ & CFI & TLI & RMSEA & SRMR \\
\hline Clan culture & 16.54 & 2 & 8.27 & 0.96 & 0.88 & 0.134 & 0.038 \\
\hline Adhocracy culture & 3.79 & 2 & 1.90 & 0.99 & 0.98 & 0.047 & 0.019 \\
\hline Hierarchical Culture & 10.55 & 2 & 5.28 & 0.90 & 0.72 & 0.103 & 0.039 \\
\hline Market culture & 5.59 & 2 & 2.80 & 0.98 & 0.94 & 0.067 & 0.029 \\
\hline Satisfaction $2^{\text {nd }}$ order & 150.67 & 51 & 2.95 & 0.93 & 0.91 & 0.069 & 0.050 \\
\hline Commitment & 91.67 & 51 & 1.80 & 0.94 & 0.93 & 0.044 & 0.045 \\
\hline
\end{tabular}

Source: the authors. 
The CFA results indicate that the latent factors generated from the items of the clan and hierarchical cultures do not present all indicators within the adequate parameters for the model. This result indicates that, in this context, the elements of these cultures present considerable variability between the respondents. On the other hand, the factors constructed from the items of the adhocracy and market cultures, as well as the satisfaction construct in the second order and commitment in the first order, present parameters within the expected values, indicating a better fit to the proposed model.

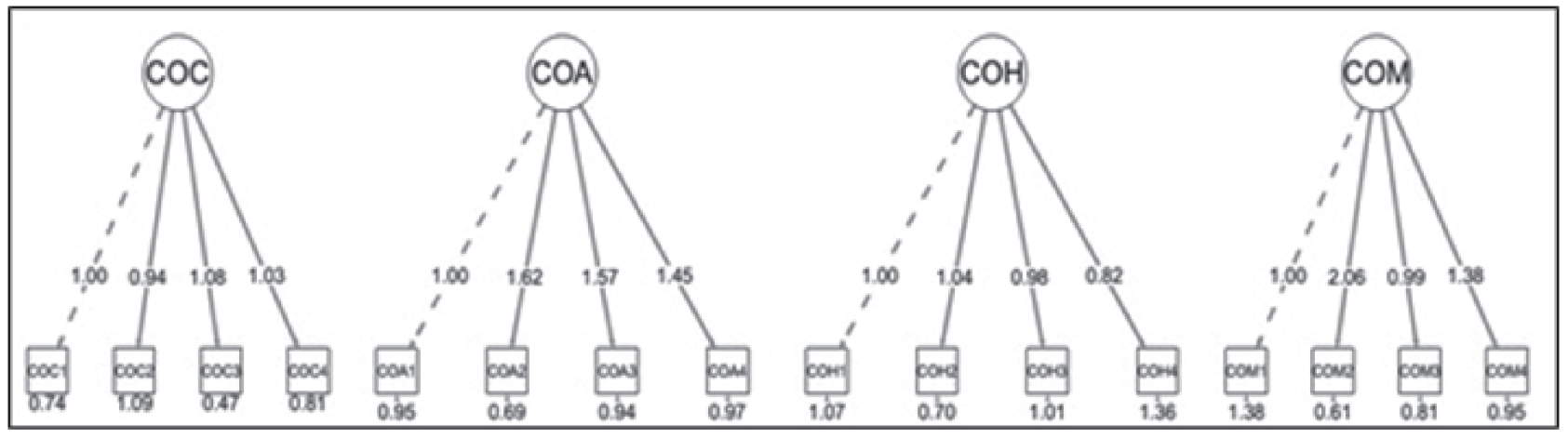

Figure 2. Confirmatory Factor Analysis for Culture

Note: $\mathrm{COC}=$ Clan Culture, $\mathrm{COA}=$ Adhocratic Culture, $\mathrm{COH}=$ Hierarchical Culture, $\mathrm{COM}=$ Market Culture

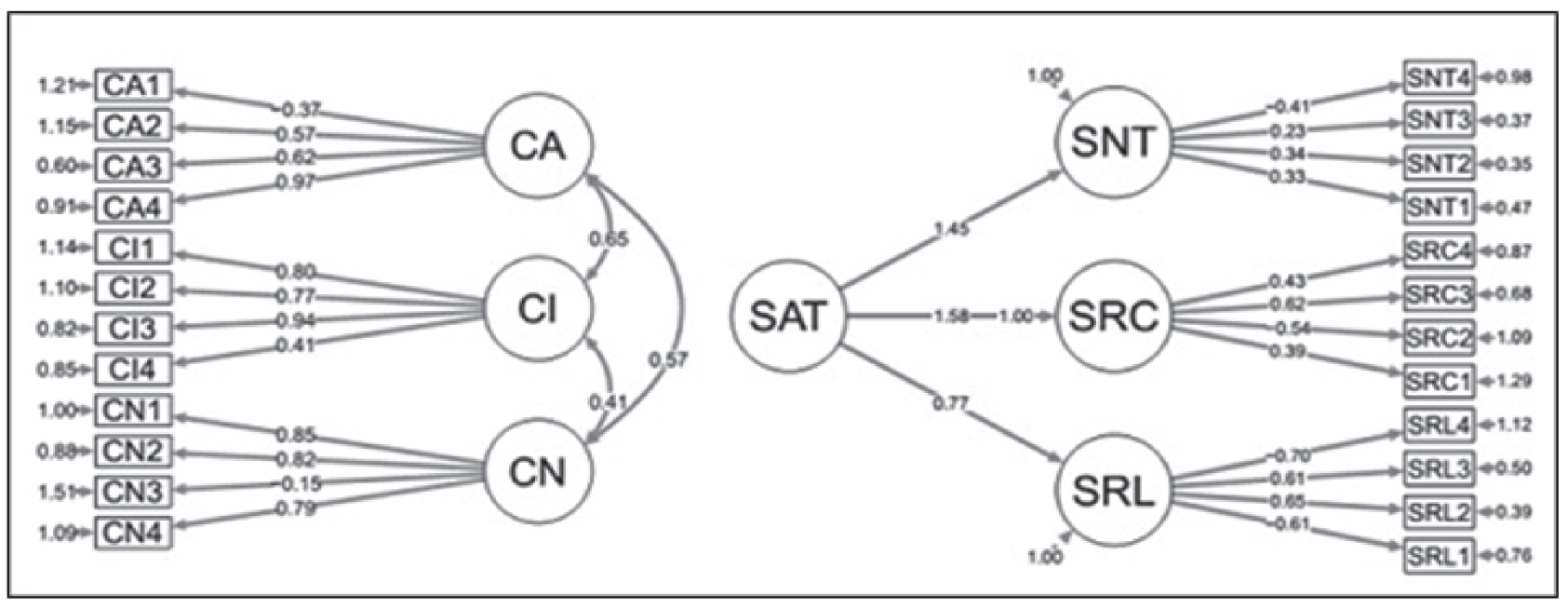

Figure 3. Confirmatory factor analysis for 1 st Order Commitment and 2nd Order Satisfaction.

Note: CA (affective commitment), CI (instrumental commitment), CN (normative commitment). SAT (satisfaction as 2nd order latent variable), SNT (nature of work), SRC (reward), SRL (relationship).

Following the CFA of the constructs, four competing models $(1,2,3$, and 4) are proposed, each model having one of the dimensions of the culture. For each concurrent model, an alternative model (1A, 2A, 3A, and 4A) was generated in which all the items were kept and included the calculations of the covariance estimators of the errors between the observed variables of the same latent construct that presented the power to reduce the value of the statistic $\chi 2$ by a value greater than 10 . This statistical adjustment has the advantage of maintaining previously established relations and improving the modeling by maintaining the empirically measured items (Hair 
et al., 2009; Maroco, 2010). Thus, in Models 1A and $2 \mathrm{~A}$, covariance estimators of errors between the items SRC1 and SRC2, SRC2 and SRC3, as well as SRC2 and SRC4, were included; likewise in Model 3A, between the items $\mathrm{COH} 1$ and COH3, SRC1 and SRC2, SRC2 and SRC4, in addition to CI2 and CI4; and also in Model 4A, between the items COM1 and COM2, COM2 and COM3, COM2 and COM4, SRC1 and SRC2, in addition to SRC2 and SRC4. Among the estimated models, adequacy of the parameters occurred in Models 1A (clan culture) and 2A (adhocratic culture), both presenting borderline values in CFI (0.90) and very close to the TLI adequacy zone (0.89).

Table 2

Results of the SEM for the culture, satisfaction, and commitment constructs

\begin{tabular}{|c|c|c|c|c|c|c|c|}
\hline Model & $\chi^{2}$ & GL & $\nabla^{2} / G L$ & CFI & TLI & RMSEA & SRMR \\
\hline Model 1 - Clan Culture & 702.39 & 337 & 2.08 & 0.89 & 0.88 & 0.052 & 0.057 \\
\hline Model 1A - Clan Culture & 656.03 & 335 & 1.96 & 0.90 & 0.89 & 0.049 & 0.056 \\
\hline Model 2 - Adhocracy Culture & 689.54 & 337 & 2.04 & 0.89 & 0.87 & 0.051 & 0.057 \\
\hline Model 2A - Adhocracy Culture & 643.88 & 335 & 1.92 & 0.90 & 0.89 & 0.048 & 0.056 \\
\hline Model 3 - Hierarchical Culture & 723.64 & 337 & 2.15 & 0.87 & 0.86 & 0.053 & 0.059 \\
\hline Model 3A - Hierarchical Culture & 665.74 & 333 & 2.00 & 0.89 & 0.87 & 0.050 & 0.057 \\
\hline Model 4 - Market Culture & 836.37 & 337 & 2.48 & 0.84 & 0.82 & 0.060 & 0.065 \\
\hline Model 4A - Market Culture & 738.57 & 332 & 2.22 & 0.87 & 0.85 & 0.055 & 0.060 \\
\hline
\end{tabular}

Source: the authors

The other indexes for these models were adequate, such as RMSEA and SRMR. Models $3 \mathrm{~A}$ and $4 \mathrm{~A}$ presented indicators outside the parameters that allow the estimators of the relationships between the latent variables to be analyzed. With regard to the estimators of the relationships between the constructs of culture, satisfaction, and the dimensions of commitment, Figure 4 presents the estimators for model $1 \mathrm{~A}$ (clan culture) and Figure 5 presents the estimators for Model 2A (adhocratic culture).

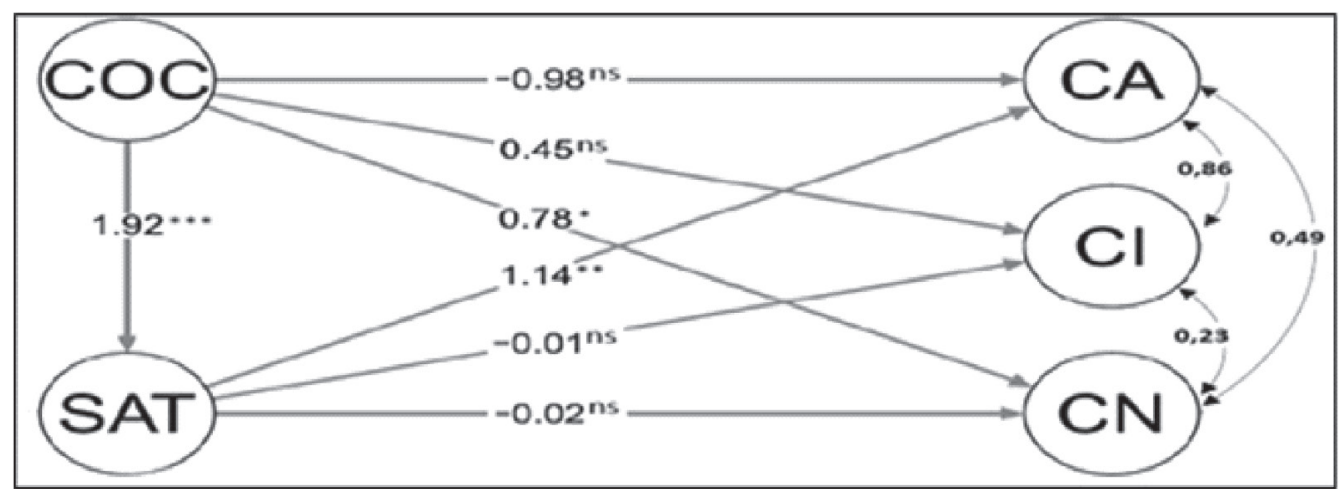

Figure 4. Model 1A (COC - clan culture) with the estimators for the structural equations modeling.

Note: Significance of the estimators: $\left({ }^{*}\right)$ p-value $<0.05,\left({ }^{* *}\right)$ p-value $<0.01,\left({ }^{* * *}\right)$ p-value $<0.001$, (ns) p-value $>0.05$ 
Model 1A, shown in Figure 4, presents the well explained satisfaction in the model $\left(\mathrm{R}^{2}\right.$ $=0.79$ ) with the estimator for the clan culture having a positive relation $(\beta=1.92)$. Thus, an increase in the presence of the elements of clan culture is expected to raise job satisfaction. An increase in the presence of clan culture elements $(\beta=0.78)$ also leads to increased normative commitment $(\mathrm{CN})$. For commitment, only the affective dimension (CA) presented a positive relationship with satisfaction $(\beta=1.14)$. Also in Model 1A, by analyzing the clan culture mediated by satisfaction (Table 3$)$, a positive $(\beta=2.19)$ and significant influence on CA can be noted, indicating that in a situation of job satisfaction, an increase in elements of clan culture leads to greater affective commitment, which does not occur when only culture is considered. This same mediation by satisfaction in culture does not generate significant estimators in IC nor in CN.

Table 3

Estimators of the SEM for the mediation by satisfaction.

\begin{tabular}{lllll}
\hline $\begin{array}{l}\text { Explanatory } \\
\text { Variable }\end{array}$ & \multicolumn{4}{l}{ Model 1A - Clan Culture } \\
& SAT & CA $(\boldsymbol{a} \times \boldsymbol{c})$ & CI $(\boldsymbol{a} \times \boldsymbol{c})$ & $\mathbf{C N}(\boldsymbol{a} \times \boldsymbol{g})$ \\
\hline $\mathrm{CULT}^{\otimes} \mathrm{SAT}$ & - & $2.19^{* *}$ & $-0.02^{\mathrm{ns}}$ & $-0.04^{\mathrm{ns}}$ \\
$\mathrm{R}^{2}$ & 0.79 & 0.73 & 0.16 & 0.36 \\
\hline
\end{tabular}

\begin{tabular}{llll}
\hline \multicolumn{4}{l}{ Model $2 \mathrm{~A}$ - Adhocratic Culture } \\
SAT & $\mathbf{C A}(\boldsymbol{a} \times \boldsymbol{c})$ & $\mathbf{C I}(\boldsymbol{a} \times \boldsymbol{c})$ & $\mathbf{C N}(\boldsymbol{a} \times \boldsymbol{g})$ \\
\hline- & $1.21^{* * *}$ & $0.23^{* *}$ & $0.18^{*}$ \\
0.44 & 0.71 & 0.12 & 0.40 \\
\hline
\end{tabular}

Note: Legend: SAT: satisfaction, CA: affective commitment, IQ: instrumental commitment, CN: normative commitment. CULT $\rightarrow$ SAT: culture mediated by satisfaction. Significance of the estimators: $\left({ }^{*}\right)$ p-value $<0.05,\left({ }^{* *}\right)$ p-value $<0.01,\left({ }^{* * *}\right)$ p-value $<0.001$, (ns) p-value $>0.05$.

Source: Authors.

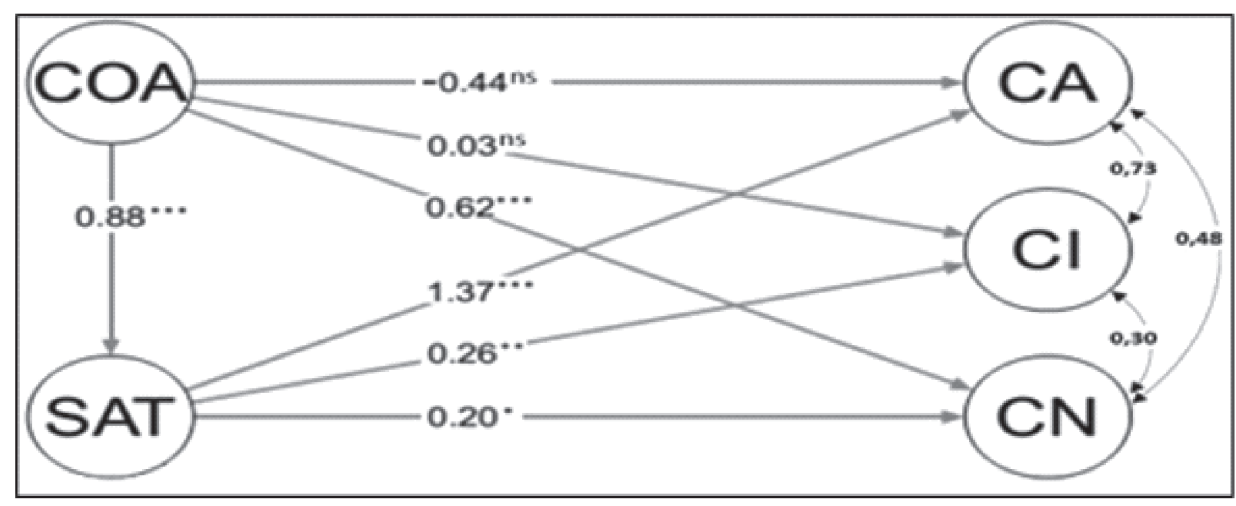

Figure 5. Model 2A (adhocratic culture) with the estimators for the structural equations modeling.

Note: Significance of the estimators: $\left(^{*}\right)$ p-value $<0.05,\left({ }^{* *}\right)$ p-value $<0.01,\left({ }^{* *}\right)$ p-value $<0.001$, (ns) p-value $>0.05$

As for Model 2A, shown in Figure 5, it shows job satisfaction influenced by the adhocratic culture $(\beta=0.88)$, with $44 \%$ of its variability being explained by the model. Affective commitment (CA) had $71 \%$ of its variability explained in the model and was positively influenced by satisfaction $(\beta=1.37)$ and by the adhocratic culture mediated by satisfaction $(\beta=1.21)$, but not by culture in a direct way. That is, an increase in the elements of the adhocratic culture can raise CA if mediated by job satisfaction. An identical process occurs with instrumental commitment, explained by satisfaction $(\beta=0.26)$ and culture mediated by satisfaction ( $\beta=0.23$ ), but not directly by culture. Complementarily, normative commitment is 
explained by $40 \%$ of all variables of the model and is positively influenced by satisfaction $(\beta=$ $0.20)$, culture $(\beta=0.62)$, and culture mediated by satisfaction $(\beta=0.18)$.

\section{I Discussion of the results}

The initial relationship between satisfaction and commitment opens up a window for discussion insofar as earlier papers usually treat commitment as a latent variable without discussing each of its dimensions (affective, normative, and instrumental) or they only deal with affective commitment (Budihargjo, 2013; Leite et al., 2014; Tett \& Meyer, 1993). These findings, regarding the adhocratic culture, are similar to the findings by Maciel and Camargo (2011), who found that satisfaction was a predictor of all types of commitment, or similar to what Leite, Rodrigues, and Albuquerque (2014) found, in studies in which satisfaction was a predictor of commitment.

As satisfaction involves affective and cognitive components (Bagliardi et al, 2012; Maciel \& Camargo, 2011; Sánchez-Sellero et al., 2014; Spector, 1985), when the individual is satisfied there is an "emotional link with the organization", which is best represented by affective commitment (Maciel \& Camargo, 2011). In this case, both models that were presented ( $1 \mathrm{~A}$ and 2A) demonstrated a significant and positive relationship between satisfaction and affective commitment. This relationship is strengthened when we observe the facets of satisfaction used in this study: promotions, relationships with supervision, and the nature of work. Individuals satisfied in the aspects that involve important dimensions of the organization can develop more intense ties with the organization that configure affective commitment.

In terms of satisfaction and culture, the results reinforce the findings of other studies, with the difference being that in the other studies (Andrade et al, 2013; Santos \& Sustelo, 2009) culture is treated as a general construct, while here the cultural types proposed by
Cameron and Quinn (2006) were considered. This favored the understanding that not all the aspects of an organization's culture are predictors of satisfaction. Considering the two cultural types treated here, the model that uses the clan culture showed a higher coefficient, indicating that this culture would produce more satisfaction if its characteristics were increased. This is in accordance with the theory described for both culture and satisfaction, since the characteristics of the clan culture are more positively associated with the concept of satisfaction than the adhocratic culture, although the latter has also been positively related to satisfaction.

These results indicate that organizations can augment the satisfaction of their employees if they develop characteristics similar to those of the clan and the adhocratic cultures, particularly those of the clan culture. This is relevant for the management of people because satisfaction, which is a predictor of other behaviors within the organization, can be amplified by the development of a culture that favors it among workers.

On the other hand, the antecedents of satisfaction are often associated with a set of factors that, together, promote the individual's affective attachment to his or her organization (Roman et al., 2012). This part of the study enhances the findings by Santos and Sustelo (2009) and Zhang and Zheng (2009). The analysis of the two cultures treated here reveals two sets of cultural characteristics that are close to what is defined by satisfaction (Locke, 1976; Imran et al., 2014; Siqueira, 2008; Spector, 1985). If, on the one hand, the clan culture indicates stronger personal relationships, integration, and cohesion of the team, the adhocratic culture involves autonomy, flexibility, and the valuing of innovation and individuality (Cameron \& Quinn, 2006). Again, these characteristics are similar to the antecedents of satisfaction presented by Tamayo (2001) and Spector (1985). This may explain the level of satisfaction associated with the adhocratic culture. On the other hand, these findings diverge in part from the findings by Alvi et al. (2014), as 
they found a significant relationship between hierarchical and clan cultures and satisfaction, a situation that may be associated with the context of their research.

As far as the relationship between culture and commitment is concerned, both clan and adhocratic cultures have been shown to predict only normative commitment. In the case of normative commitment, the individual remains in the organization because he/she believes that he/she does things correctly and identifies with it (Bastos, 1993; Medeiros et al., 2003; Weiner, 1982). Considering the cultural characteristics of the clan and the adhocracy, it is possible to infer degrees of relationships between the cultural characteristics of these types and normative commitment. By observing that culture is seen as a set of values that guide the behavior of the individual, indicating appropriate behavior, it is possible that individuals, influenced by cultural values, absorb organizational values that would lead them to believe that the organization is morally correct, signaling that they cannot abandon it.

In the case of organizational culture influencing commitment mediated by satisfaction, it is possible to verify, in the case of the clan culture model, that there is no standard for the effects on commitment in all dimensions affective, normative, and instrumental - which demonstrates the complexity of the relationships between these constructs (Maciel \& Camargo, 2011). With mediation, the clan culture, which was not significant in terms of affective commitment, becomes so. In the case of its direct effect, clan culture was a predictor of normative commitment, but when mediated by satisfaction it no longer affects it. Instrumental commitment did not present any significance in any of the relations with clan culture. Since clan culture and satisfaction have a strong affective component, they differ from the idea of instrumental commitment. Still, mediation by satisfaction seems to indicate that its relationship with clan culture leads to more affective commitment than the other types of commitment, as in the organizational context it increases affective bonds with the organization. This indicates that higher levels of affective commitment seem to be what would generate the greatest performance for organizations, since the individual remains in the organization because he/she wants to (Allen \& Meyer, 1990; Fu, Bohlander, \& Jones, 2009; Jaros, 2007; Maciel \& Camargo, 2011). The cultural values associated with the clan culture were also mediated by better satisfaction rates.

On the other hand, the adhocratic culture was shown to be positively associated with all the dimensions of commitment when it is mediated by satisfaction. The effect of satisfaction is so important that when the effect of the adhocratic culture on affective commitment is verified, no statistical significance is noted; but by inserting satisfaction as a mediator, affective commitment becomes significant and positive, indicating that satisfaction can be used to predict levels of commitment. Something similar happens with the relationship between adhocratic culture and instrumental commitment. It is suggested that the characteristics of this culture, such as flexibility, individuality, entrepreneurship, and relation with the external environment, are prone to generating this type of commitment, since within it the main characteristic is the exchange that the individual makes with the organization (Meyer \& Allen, 1991). As the dimensions of satisfaction used in this study contain elements such as promotion opportunities, which ultimately value or develop individuality and self interest, this possibly explains the instrumental commitment being predicted by the adhocratic culture mediated by satisfaction.

In both models that were treated, the important role of satisfaction in both clan and adhocratic cultures is observed, especially in the adhocratic culture, where it can predict all types of commitment. Alone, clan and adhocratic cultures are only predictive of normative commitment. Although culture is an important dimension in the organizational context, as it reflects the 
values, meanings, and assumptions of the group (Cameron \& Quinn, 2006; Geertz, 1989; Schen, 2004), it seems to play a less relevant role compared to when it is mediated by satisfaction. This reinforces the importance of considering the behavior of individuals within the organization as a complex phenomenon that derives from a variety of elements that are not always easily identifiable and measurable (Leite et al., 2014; Maciel \& Camargo, 2011).

\section{Conclusion}

The findings of this study reinforce the research already carried out that uses satisfaction as an antecedent and a predictor of commitment, as well as reinforcing other studies that relate organizational culture and satisfaction. However, this paper seeks to contribute further by using culture mediated by satisfaction to explain levels of commitment, since there is still space for new research to discuss these relationships. The most relevant results involve the influence of satisfaction as a mediator between culture and commitment. It should be noted that of the cultural types proposed by Cameron and Quinn (2006), only the clan and adhocratic cultures proved to be adequate for the analyses carried out here. In these, clan and adhocratic cultures are able to predict commitment to a greater extent when mediated by satisfaction. This indicates that satisfaction plays a relevant role in the relationship between culture and commitment, since alone these two cultures affect few aspects of commitment. When mediated by satisfaction, they are more effective in this process.

This reinforces what has been said about the complexity of organizational phenomena (Morgan, 1996) and the need to consider organizational analyses from a variety of perspectives, even though this makes the analysis processes more complex. Thus, the main contribution of this work lies in its presentation of the significant effects of satisfaction as a mediator in the relationship between culture and commitment, since inserting satisfaction in this relationship increases the levels of commitment in the three dimensions - affective, normative, and instrumental - especially in the case of adhocratic culture.

In terms of the main limitations of this study, the CFAs of the clan and adhocratic cultures suggest the need to improve the instruments for measuring these variables. Another limitation concerns the sample and its banking context, since this involved only one organizational unit. This impedes these results from being generalized or adopted as fully adequate to explain the relations between the variables. We suggest that new research be carried out and a research agenda be followed so that these relationships can be tested in order to see the behavior of these variables in different contexts. We also suggest the use of the other dimensions of satisfaction and the totalization of the items of the culture scale in new studies in order to verify if new relationships are identified between these constructs.

\section{References}

Allen, N. J., \& Meyer, J. P. (1990). The measurement and antecedents of effective, continuance and normative commitment to organization. Journal of occupational Psychology, 63,1-18.

Alvesson, M. (2007). Understanding Organizational Culture. London: SAGE Publications.

Alvi, H. A, Hanif, M., Adil, M. S., Ahmed, R. R., \& Vveinhardt, J. (2014). Impact of organizational culture on organizational commitment and job satisfaction. European Journal of Business and Management, 6(27), 30-40.

Andrade, T., Costa, V. F, Estivavalete, V. F. B., \& Lengler, L. (2017). Comportamento de cidadania organizacional: Um olhar à luz dos valores e da satisfação no trabalho. Revista Brasileira de Gestão de Negócios, 19(64), 236-262.

Andrade, T., Limanas, S., Estivalete, V. F. B., \& Tanscheit, F. (2013). Cultura organizacional e satisfação no trabalho sob a percepção dos colaboradores de uma instituição bancária após o 
processo de fusão. Revista Administração e Diálogo, 15(2), 52-78.

Bandeira, M. L., Marques, A. L., \& Veiga, R. T. (2000). As dimensôes múltiplas do comprometimento organizacional: Um estudo na ECT/MG. Revista de Administração Contemporânea, 4(2), 133-157.

Bastos, A. V. B. (1993). Comprometimento Organizacional: Um balanço dos resultados e desafios que cercam essa tradição de pesquisa. Revista de Administração de Empresas, 33(3), 52-64.

Bastos, A. V. B. (1994). Comprometimento no trabalho: A estrutura dos vinculos do trabalhador com a organização, a carreira e o sindicato (Tese Doutorado). Universidade de Brasília, Brasília, DF, Brasil.

Becker, H. S. (1960). Notes on the Concept of Commitment. The American Journal of Sociology, 66(1), $32-40$.

Bigliardi, B., Dormio, A. I., Galati, F., \& Schiuma, G. (2012). The impact of organizational culture on the job satisfaction of knowledge workers. VINE, 42(1), 36 - 51.

Braga, G. G. A., Ferraz, S. F. S., \& Lima, T. C. B. (2014). Cultura organizacional em empresas industriais: Um estudo nas maiores empresas de Maracanaú/CE. Revista Eletrônica de Ciência Administrativa, 13(2), 250-266.

Budihardjo, A. (2013). The relationship between job satisfaction, affective commitment, organizational learning climate and corporate performance. GSTF Journal on Business Review, 2(4), 58-64.

Cameron, K. S., \& Quinn, R. E. (2006). Diagnosing and changing organizational culture - Based on the competing values framework. San Francisco, CA: Jossey-Bass.

Denison, D. R., \& Spreitzer, G. M. (1991). Organizational culture and organizational development: A competing values approach. Research in Organizational Change and Development, 5, 1-21.
Falkenburg, K., \& Schyns, B. (2007). Work satisfaction, organizational commitment and withdrawal behaviors. Management Research News, 30(10), 708-723.

Fernandes, R. F., Lemos, D. C., Hoffmann, M. G., \& Feuerchutte, S. G. (2015). O Estado da Arte na Articulação entre os Temas Cultura Organizacional e Inovação. Revista Pensamento Contemporâneo em Administração, 9(4), 54-68.

Fu, F. Q., Bohlander, W., \& Jones, E. (2009). Managig the drivers of organizational commitment and salesperson effort: An application of Meyer and Allen's three-component Model. Journal of Marketing Theory and Practice, 17(4), 335-350.

Geertz, C. (1989). A interpretação das culturas. Rio de Janeiro: Guanabara Koogan, 1989.

Gull, S., \& Azam, F. (2012). Impact of organizational culture type on job satisfaction level of employees in different organizations of Lahore. International Journal of Academic Research in Business and Social Sciences, 2(12), 97-112.

Habib, S., Aslam, S., Hussain, A., Yasmeen, S., \& Ibrahim, M. (2014). The impact of organizational culture on job satisfaction, employess commitment and turn over Intention. Advances in Economics and Business, 2(6), 215-222.

Hair, J. F., Black, W. C., Babin, B. J., Anderson, R. E., \& Tatham, R. L. (2009). Análise multivariada de dados. Porto Alegre: Bookman.

Hartnell, C. A., Ou, A. Y., \& Kinicki, A. (2011). Organizational culture and organizational effectiveness: A meta-analytic investigation of the competing values framework's theorical suppositions. Journal of Applied Psychology, 96(4), 677-694.

Hauff, S., Richter, N. F., \& Tressin, T. (2015). Situational job characteristics and job satisfaction: The moderating role of national culture. International Business Review, 24, 710-723.

Imran, H., Arif, I., Cheema, S., \& Azeem, M. (2014). Relationship between job satisfaction, 
job performance, attitude towards work, organizational commitment. Entrepreneurship and Innovation Management Journal, 2(2), 135-144.

Jaros, S. (2007). Meyer and Allen Model of organizational commitment: Measurement issues. The ICFAL Jornal of organizational Behavior, 6(4), 7-25.

Leite, N. R. P., Rodrigues, A. C. A., \& Albuquerque, L. G. (2014). Organizational commitmrny and satisfaction: What are the potential relations? Brazilian Administration Review, 11(4), 476-495.

Lima, C. Q. B., Barbosa, C. M. G., Mendes, R. W. B., \& Patta, C. A. (2014). Assédio moral e violência no trabalho: Caracterização em perícia judicial - Relato de experiência no setor bancário. Revista Brasileira de Saúde Ocupacional, 39(129), 101-110.

Locke, E. A. (1976). The nature and causes of job satisfaction. In M. D. Dunnette (Ed.), Handbook of industrial and organizational psychology (1297-1349). Chicago: Rand McNally.

Maciel, C. O., Camargo, C. (2011). Comprometimento, satisfação e cooperação no trabalho: Evidências da primazia dos aspectos morais e das normas de reciprocidade sobre o comportamento. Revista de Administração Contemporânea, 15(3), 433-453.

Marôco, J. (2010). Análise de equaçôes estruturais. Pero Pinheiro: Report Number.

Martins, M. C. F., \& Santos, G. E. (2006). Adaptação e validação de construto da Escala de Satisfação no Trabalho. Psico-USF, 11(2), 195-205.

Medeiros, C. A. F., \& Albuquerque, L. G. (2005). Comprometimento organizacional: Um estudo de suas relaçóes com características organizacionais e desempenho nas empresas Hoteleiras. Revista Psicologia Organização e Trabalho, 5(2), 35-64.

Medeiros, C. A. F., Albuquerque, L. G., Siqueira, M., \& Marques, G. M. (2003). Comprometimento Organizacional: $\mathrm{O}$ estado da arte da pesquisa no
Brasil. Revista de Administração Contemporânea, 7(4), 198-209.

Medeiros, C. A. F., Enders, W. T. (1998). Validação do modelo de conceitualização de três componentes do comprometimento organizacional (Meyer e Allen, 1991). Revista de Administração Contemporânea, 2(3), 67-87.

Meyer, J. P., Allen, N. J. (1991). A threecomponent conceptualization of organizational commitment. Human Resource Management Review, 1(1), 61-89.

Morgan, G. (1996). Imagens da Organização. São Paulo: Atlas.

Mowday, R. T., Steers, R. M., \& Porter, L. W. (1979). The Measurement of organizational commitment. Journal of Vocational Behavior, 14, 224-247.

Oliveira, L. B., \& Costa, F. P. C. (2016). Motivação, satisfação e comprometimento: Um estudo sobre o trabalho voluntário em megaeventos esportivos. Revista Economia \& Gestão, 16(42), 89-115.

Olsson, U. H., Foss, T., Troye, S. V., \& Howell, R. D. (2000). The performance of ML, GLS and WLS estimation in structural equation modelling under conditions of misspecification and nonnormality. Structural Equation Modeling, 7(4), 557-595.

Pires, V. M., Costa, L. V., \& Siqueira, M. M. (2015). O impacto do comprometimento afetivo e do engajamento no trabalho sobre os comportamentos de cidadania organizacional. Revista de Administração Contabilidade e Economia da FUNDACE, 6(2), 1-1.

Quinn, R. E., \& Rohrbaugh, J. (1983). A spatial model of effectiveness criteria: Towards a competing values approach to organizational analysis. Management Science, 29, 363-377.

Rocha, E. S., \& Honório, L. C. (2015). Comprometimento com o trabalho: $\mathrm{O}$ caso dos chefes de seçóes de infraestrutura da 
UFMG. Revista Ciências Administrativas, 21(1), 237-261.

Rodrigues, A. L., Barrichello, A., \& Morin, E. (2016). Os sentidos do trabalho para profissionais de enfermagem: Um estudo multimétodos. Revista de Administração de Empresas, 56(2), 192-208.

Roman, S., Stefano, S. R., Aandrade, S. M., \& Zampier, M. A. (2012). Análise do comprometimento organizacional e sua natureza em relação aos funcionários públicos municipais. Gestão \& Regionalidade, 28(84), 5-19.

Rosseel, Y. (2012). Lavaan: A R package for equation Structural Modelling. Journal of Statistical Software, 48(2), 1-36.

Sanchez-Sellero, M. C., Sánchez-Sellero, P., Cruz-González, M. M., \& Sánchez- Sellero, F. J. R. (2014). Características organizacionales de la satisfacción laboral en España. Revista de Administração de Empresas, 54(5), 537-547.

Santos, J. V., \& Sustelo, M. (2009). Cultura organizacional e satisfação profissional: Estudo desenvolvido num hospital privado. Revista Psicologia Organizaçâo e Trabalho, 40(4), 467-472.

Schein, E. (2004). Organizational culture and leadership (3a ed.). San Francisco: Jossey-Bass.

Silva, E. C., \& Bastos, A. V. B. (2010). A escala de consentimento organizacional: Construção e evidência de validade. Revista Psicologia, Organizaçôes e Trabalho, 10(1), 7-22.

Silva, L. P., Castro, M. A. R., \& Santos, M. G., dos. (2018). Influência da cultura organizacional mediada pelo assédio moral na satisfação no trabalho. Revista de Administração Contemporânea, 22(2), 249-270.

Siqueira, M. M. M. (2008). Satisfação no trabalho. In M.M.M Siqueira (Org), Medidas do comportamento organizacional: Ferramentas de diagnóstico e de gestão (pp. 265-274). Porto Alegre: Artmed.

Siqueira, M. M. M., \& Gomide, S. G., Jr. (2004). Vínculos do indivíduo com o trabalho e com a organização. In J. C. Zannelli, J. E. BorgesAndrade, A. V. B. Bastos. Psicologia, organizaçôes e trabalho no Brasil(300-330). Porto Alegre: Artmed.

Spector, P. E. (1985). Measurement of human service staff satisfaction: Development of the job satisfaction survey. American Journal of Community Psychology, 13(6), 693-713.

Spector, P. E. (2006). Psicologia nas Organizaçôes (2a ed.). São Paulo: Saraiva.

Strese, S., Adams, D. R., Flatten, T. C., \& Brettel, M. (2016). Coporative culture and absorptive: The moderating role of national culture dimensions on innovation management. International Business Review, 25(5), 1149-1168

Tamayo, A. (2001). Prioridades axiológicas, atividade física e estresse ocupacional. Revista de Administração Contemporânea, 5(3), 127-147.

Tett, R. P., \& Meyer, J. P. (1993). Job satisfaction, organizational commitment, turnover intention, and turnover: Path analuses based on metaanalytic finds. Personnel Psychology, 46, 259-293.

Vieira, V. A. (2009). Moderação, mediação, moderadora-mediadora e efeitos indiretos em modelagem de equaçóes estruturais: Uma aplicação no modelo de desconfirmação de expectativas. Revista de Administração, 44(1), 17-33.

Warr, P. (2007). Work, happiness, and unhappiness. Mahwah, NJ: Lawrence Erlbaum.

Wiener, Y. (1982). Commitment in organizations: A normative view. Academy of Management Review, 7(3), 418-428.

Zhang, J., \& Zheng, W. (2009). How does satisfaction translate into performance? An examination of commitment and cultural values. Human Resource Development Quarterly, 20(3), 331-351. 


\section{APPENDIX A}

Dear Respondent,

We are conducting a study on the various aspects of an organization. It will be of great value if you can spend about 15-20 minutes filling out this questionnaire. The information provided will be kept confidential. This questionnaire is part of a study developed within the Master of Business Administration post-graduate program at Salvador University.

\begin{tabular}{|c|c|c|c|}
\hline Code/Factor & Meaning & Classes & Assigned Values \\
\hline \multirow{6}{*}{ fxet } & \multirow{6}{*}{ Age Group } & less than 21 years old & 1 \\
\hline & & $21-30$ years old & 2 \\
\hline & & $31-40$ years old & 3 \\
\hline & & $41-50$ years old & 4 \\
\hline & & $51-60$ years old & 5 \\
\hline & & more than 60 years old & 6 \\
\hline \multirow{2}{*}{ gn } & \multirow{2}{*}{ Gender } & Male & 1 \\
\hline & & Female & 2 \\
\hline \multirow{4}{*}{ ec } & \multirow{4}{*}{ Marital Status } & Married & 1 \\
\hline & & Stable Union & 2 \\
\hline & & Divorced & 3 \\
\hline & & Single & 4 \\
\hline \multirow{6}{*}{ esc } & \multirow{6}{*}{ Education } & Secondary Level & 1 \\
\hline & & Higher incomplete & 2 \\
\hline & & Higher & 3 \\
\hline & & Specialization & 4 \\
\hline & & Master & 5 \\
\hline & & Doctorate & 6 \\
\hline \multirow{8}{*}{ aform } & \multirow{8}{*}{ Area of Major } & Business Administration & 1 \\
\hline & & Accounting & 2 \\
\hline & & Economics & 3 \\
\hline & & Psychology & 4 \\
\hline & & Engineering & 5 \\
\hline & & Law & 6 \\
\hline & & Communication & 7 \\
\hline & & Other & 8 \\
\hline \multirow{2}{*}{ fun } & \multirow{2}{*}{ Position } & Management & 1 \\
\hline & & Technical & 2 \\
\hline \multirow{6}{*}{ temp } & \multirow{6}{*}{ Time in the Company } & Up to 5 years & 1 \\
\hline & & Between 5 and 10 years & 2 \\
\hline & & Between 10 and 15 years & 3 \\
\hline & & Between 15 and 20 years & 4 \\
\hline & & Between 20 and 25 years & 5 \\
\hline & & More than 25 years & 6 \\
\hline
\end{tabular}


The following statements should be answered by assigning your level of agreement to each of them using the following values: 1 - totally disagree; 2 - partially disagree; 3 - Neither agree nor disagree; 4 - partially agree; and 5 - totally agree

\begin{tabular}{|c|c|}
\hline Item & Description \\
\hline 1 & $\begin{array}{l}\text { One of the main reasons I continue to work for this organization is that I believe that loyalty is important and therefore feel a } \\
\text { sense of moral obligation to remain. }\end{array}$ \\
\hline 2 & My job is enjoyable. \\
\hline 3 & $\begin{array}{l}\text { The glue that holds the organization together is commitment to innovation and development. There is an emphasis on being } \\
\text { on the cutting edge. }\end{array}$ \\
\hline 4 & My supervisor is unfair to me. \\
\hline 5 & The leadership in the organization is generally considered to exemplify an aggressive, results-oriented focus. \\
\hline 6 & It would be very hard for me to leave my organization right now, even if I wanted to. \\
\hline 7 & People get ahead as fast here as they do in other places. \\
\hline 8 & The organization is a very controlled and structured place. Formal procedures generally govern what people do. \\
\hline 9 & I like my supervisor. \\
\hline 10 & The management style in the organization is characterized by teamwork, consensus, and participation. \\
\hline 11 & $\begin{array}{l}\text { One of the main reasons I continue to work for this organization is that leaving would require considerable personal sacrifice - } \\
\text { another organization may not match the overall benefits I have here. }\end{array}$ \\
\hline 12 & I like doing the things I do at work. \\
\hline 13 & $\begin{array}{l}\text { The glue that holds the organization together is formal rules and policies. Maintaining a smooth-running organization is } \\
\text { important. }\end{array}$ \\
\hline 14 & I was taught to believe in the value of remaining loyal to one organization \\
\hline 15 & The leadership in the organization is generally considered to exemplify entrepreneurship, innovation, or risk taking. \\
\hline 16 & I think that I could easily become as attached to another organization as I am to this one. \\
\hline 17 & There is really little chance for promotion in my job. \\
\hline 18 & The management style in the organization is characterized by hard-driving competitiveness, high demand, and achievement. \\
\hline 19 & I really feel as if the organizational problems are my own. \\
\hline 20 & The organization is a very personal place. It is like an extended family. People seem to share a lot of themselves. \\
\hline 21 & Too much in my life would be disrupted if I decided I wanted to leave my organization now. \\
\hline 22 & I am satisfied with my chances for promotion. \\
\hline 23 & The leadership in the organization is generally considered to exemplify coordinating, organizing, or smooth-running efficiency. \\
\hline 24 & I feel a sense of pride in doing my job. \\
\hline 25 & The glue that holds the organization together is loyalty and mutual trust. Commitment to this organization is high. \\
\hline 26 & Jumping from organization to organization does not seem at all unethical to me. \\
\hline 27 & My supervisor is competent in doing his/her job. \\
\hline 28 & The management style in the organization is characterized by individual risk taking, innovation, freedom, and uniqueness. \\
\hline 29 & This organization has a great deal of personal meaning for me. \\
\hline 30 & Those who do well on the job stand a fair chance of being promoted. \\
\hline 31 & The glue that holds the organization together is the emphasis on achievement and goal accomplishment. \\
\hline 32 & Right now, staying with my organization is a matter of necessity as much as desire. \\
\hline 33 & The leadership in the organization is generally considered to exemplify mentoring, facilitating, or nurturing. \\
\hline 34 & I sometimes feel my job is meaningless. \\
\hline 35 & $\begin{array}{l}\text { The management style in the organization is characterized by security of employment, conformity, predictability, and stability } \\
\text { in relationships. }\end{array}$ \\
\hline 36 & If I got another offer for a better job elsewhere, I would not feel it was right to leave my organization. \\
\hline 37 & The organization is a very dynamic and entrepreneurial place. People are willing to stick their necks out and take risks. \\
\hline 38 & I would be very happy to spend the rest of my career with this organization. \\
\hline 39 & My supervisor shows too little interest in the feelings of subordinates. \\
\hline 40 & $\begin{array}{l}\text { The organization is very results-oriented. A major concern is getting the job done. People are very competitive and } \\
\text { achievement-oriented. }\end{array}$ \\
\hline
\end{tabular}




\section{Notes:}

1 A preliminary version of "A relação entre cultura organizacional e comprometimento no trabalho mediada pela satisfação" was presented at XX SEMEAD, November 08-10, 2017, in São Paulo.

\section{About the Authors:}

1. Lindomar Pinto da Silva, PhD in Business Administration, Federal University of Bahia, Brazil.

Email: lindomar.silva@unifacs.br

\section{ORCID}

\section{(iD 0000-0002-1138-8165}

2. Miguel Angel Rivera Castro, PhD in Economics, University of Santiago de Compostela, Spain.

Email: miguel.castro@unifacs.br

ORCID

(iD) 0000-0002-4728-3242

3.Marcos Gilberto Dos-Santos, Master in Management, Salvador University, Brazil. Email: marcosgilberto74@gmail.com.

ORCID

(iD) 0000-0002-1021-9837

4. Pedro José Lima Neto, Specialist, Fundação Getúlio Vargas, Brazil. Email: pedrojn@bnb.gov.br ORCID

(iD 0000-0002-5471-8267

\section{Contribution of each author}

\begin{tabular}{|c|c|c|c|c|}
\hline Contribution & $\begin{array}{c}\text { Lindomar } \\
\text { Pinto da Silva }\end{array}$ & $\begin{array}{c}\text { Miguel } \\
\text { Angel Rivera } \\
\text { Castro }\end{array}$ & $\begin{array}{c}\text { Marcos } \\
\text { Gilberto dos } \\
\text { Santos }\end{array}$ & $\begin{array}{l}\text { Pedro José Lima } \\
\text { Neto }\end{array}$ \\
\hline 1. Definition of research problem & $\sqrt{ }$ & $\sqrt{ }$ & $\sqrt{ }$ & \\
\hline $\begin{array}{l}\text { 2. Development of hypotheses or research questions } \\
\text { (empirical studies) }\end{array}$ & $\sqrt{ }$ & $\sqrt{ }$ & & $\sqrt{ }$ \\
\hline 3. Development of theoretical propositions (theoretical work) & $\sqrt{ }$ & $\sqrt{ }$ & & $\sqrt{ }$ \\
\hline 4. Theoretical foundation/Literature review & $\sqrt{ }$ & & & $\sqrt{ }$ \\
\hline 5. Definition of methodological procedures & $\sqrt{ }$ & $\sqrt{ }$ & $\sqrt{ }$ & \\
\hline 6. Data collection & $\sqrt{ }$ & & & $\sqrt{ }$ \\
\hline 7. Statistical analysis & & $\sqrt{ }$ & $\sqrt{ }$ & \\
\hline 8. Analysis and interpretation of data & $\sqrt{ }$ & $\sqrt{ }$ & $\sqrt{ }$ & \\
\hline 9. Critical revision of the manuscript & $\sqrt{ }$ & $\sqrt{ }$ & $\sqrt{ }$ & \\
\hline 10. Manuscript writing & $\sqrt{ }$ & $\sqrt{ }$ & $\sqrt{ }$ & \\
\hline
\end{tabular}

